\title{
Penggunaan Deiksis dalam Acara "Mata Najwa" di Trans7 Episode April 2020 (Jokowi Diuji Pandemi)
}

\author{
Susi Susanti ${ }^{1)}$ \\ Universitas Indraprasta PGRI \\ Jalan Nangka No. 58 C/TB. Simatupang, Tanjung Barat, Jakarta Selatan 12530 \\ Sumaryoto ${ }^{2}$ \\ Universitas Indraprasta PGRI \\ Jalan Nangka No. 58 C/TB. Simatupang, Tanjung Barat, Jakarta Selatan 12530 \\ Bambang Sumadyo $^{\mathbf{3})}$
Universitas Indraprasta PGRI
Jalan Nangka No. 58 C/TB. Simatupang, Tanjung Barat, Jakarta Selatan 12530
}

Susantis189@gmail.com ${ }^{1)}$

\begin{abstract}
This study aims to determine the use of deixis in the Mata Najwa event in the April 2020 Trans 7 Episode (Jokowi Tested Pandemic) and its implications for learning Indonesian. This research use desciptive qualitative approach. The results of this study are: 1) There is a purpose of deixis in the Mata Najwa conversation, including persona deixis with the aim of being an object, subject, and possession. The purpose of the space deixis only shows the description of places and objects. The purpose of a time deixis refers only to past, present, and past time information. In addition, the context of using deixis is based on the topic of discussion, situation, social status of a person, kinship, formality, the speaker's habits, and the designation of an object; 2) There are implications in this research, namely, based on the 2013 Curriculum in accordance with Basic Competencies: students present information data in the form of news orally and in writing by paying attention to linguistic characteristics, namely the use of pronouns (pronouns), use of direct and indirect sentences and usage. information of place and time in accordance with the context. Thus, it can be concluded that the use of deixis has implications for learning Indonesian in schools.
\end{abstract}

Keywords: Deixis, Mata Najwa Trans7, implication, Indonesian language learning

\begin{abstract}
Abstrak
Penelitian ini bertujuan untuk mengetahui penggunaan deiksis di dalam acara Mata Najwa di Trans7 Episode April 2020 (Jokowi Diuji Pandemi) dan implikasinya terhadap pembelajaran Bahasa Indonesia. Penelitian ini menggunakan pendekatan deskriptif kualitatif. Adapun hasil dari penelitian ini yaitu: 1) Terdapat tujuan deiksis dalam percakapan acara Mata Najwa, meliputi deiksis persona dengan tujuan mengarah sebagai objek, subjek, dan kepunyaan. Tujuan deiksis ruang hanya menunjukkan keterangan tempat dan objek. Tujuan deiksis waktu hanya mengacu pada keterangan waktu lampau, kini, dan lalu. Selain itu, tujuan konteks penggunaan deiksis antara lain didasari oleh topik pembicaraan, situasi, status sosial seseorang, hubungan kekerabatan, formalitas, kebiasaan penutur, serta penunjukkan suatu objek; 2) Terdapat implikasi pada penelitian ini yaitu, berdasarkan Kurikulum 2013 sesuai dengan Kompetensi Dasar: siswa menyajikan data informasi dalam bentuk berita secara lisan dan tulis dengan memperhatikan ciri kebahasaan, yaitu penggunaan kata ganti orang (pronominal), penggunaan kalimat langsung dan tidak langsung serta penggunaan keterangan tempat dan waktu yang sesuai dengan konteksnya.
\end{abstract}


Dengan demikian, dapat disimpulkan bahwa pengunaan deiksis memiliki implikasi dalam pembelajaran Bahasa Indonesia di sekolah.

Kata Kunci: Deiksis, Mata Najwa Trans7, implikasi, pembelajaran Bahasa Indonesia

\section{PENDAHULUAN}

Bahasa merupakan suatu perbuatan yang dilakukan oleh setiap manusia dalam kebersamaannya dengan manusia lain untuk berkomunikasi. Bahasa sebagai sarana komunikasi dapat berupa bahasa lisan, maupun bahasa tulis. Bahasa merupakan ciri utama yang membedakan manusia dengan makhluk lainnya dan tidak dapat dipisahkan dari kehidupan manusia. Bahasa selalu muncul dalam segala aspek kegiatan manusia. Penggunaan bahasa, memiliki berbagai variasi yang disesuaikan dengan situasi dan kondisi yang ada, tanpa mengabaikan kaidah penggunaan bahasa.

Berbahasa merupakan upaya sadar yang digunakan oleh seseorang untuk mengungkapkan ide, perasaan, dan kesan pikiran yang dimiliki agar orang lain mengetahui apa maksud dan tujuan pembicara. Dalam sebuah percakapan terdapat factor-faktor yang mempengaruhi pemakaian bahasa yang baik dan benar, antara lain, siapa dan peristiwa apa yang terjadi dalam suatu pembicaraan, masalah yang dibicarakan, waktu ketika berbicara, tempat ketika berbicara dan sebagainya. Factor-faktor tersebut dapat mempengaruhi pemakaian bahasa yang digunakan oleh seorang pembicara.

Dalam tindak komunikasi lisan, manusia menggunakan ujaran-ujaran yang memiliki berbagai makna. Makna dari sebuah ujaran berbeda-beda tergantung dari konteks situasi di mana ujaran itu digunakan. Bahasa merupakan alat komunikasi yang paling baik di antara alat-alat komunikasi lainnya. Apabila dibandingkan dengan alat komunikasi yang digunakan makhluk sosial lain, yakni hewan. Dalam setiap komunikasi, manusia saling menyampaikan informasi yang dapat berupa pikiran, gagasan, maksud, perasaaan, maupun emosi secara langsung. Oleh karena itu, untuk memahami makna dari sebuah tindak komunikasi kita harus mengkaji ujaran tersebut secara pragmatik.

Yule (2014:3) mengemukakan bahwa "pragmatic adalah makna yang disampaikan oleh penutur (atau penulis) dan ditafsirkan oleh pendengar (atau pembaca). Artinya, pragmatic melihat bahasa berdasarkan penutur dan mitra tutur. Hal ini dikarenakan, pragmatic dilihat berdasarkan factor-faktor eksternal seperti, penutur, mitra tutur, waktu penutur, tempat tuturan, situasi tuturan, tujuan tuturan, situasi dan peristiwa tuturan. Hubungan sosial antara penutur dan pendengar terjalin melalui komunikasi. Dalam hal ini, bahasa sebagai alat komunikasi mempunyai peranan yang sangat penting dalam interaksi sosial. Hal tersebut terdapat pada pemilihan kata yang berwujud deiksis selalu berubah-ubah dan bergantung pada konteks. Kata-kata seperti saya, dia, kami, sekarang, kemarin, di sini, di sana, ini, itu, merupakan kata deiktis, kata tersebut mempunyai makna yang berpindah-pindah tergantung siapa penuturnya, siapa lawan tuturnya, bagaimana situasi, dan lainnya.

Pragmatic adalah sebuah bidang keilmuan di ranah kebahasaan yang memelajari makna suatu penuturan yang melibatkan konteks, memahami makna 
penuturan lebih dari yang dituturkan, atau makna lain dari makna kata-kata yang dituturkan (Yule dalam Nurgiyantoro, 2018: 26). Selanjutnya pengertian pragmatik adalah "telaah mengenai hubungan antara bahasa dan konteks yang tergramatisasikan atau disandikan dalam struktur suatu bahasa (Tarigan, 2009: 30). Maksud pernyataantersebut bahwa pragmatik adalah hubungan bahasa dan konteks yang sudah mengalami gramatisasi dalam struktur bahasa.

Bahasa digunakan manusia untuk menyampaikan beragam informasi dalam berbagai bentuk media, seperti media televisi, surat kabar, radio, dan sebagainya. Sehubungan dengan itu, penggunaan dieksis dapat dijumpai pada percakapan lisan maupun tulisan. Percakapan lisan tidak hanya dapat ditemukan secara langsung, melainkan dapat dijumpai pula pada pada percakapan di acara telivisi maupun radio. Misalnya, percakapan dalam acara "Mata Najwa" di televisi. Acara "Mata Najwa" di televisi menghadirkan macam-macam jenis dan bentuk pemakaian deiksis dapat ditemukan. Menurut Djajasudarma "istilah deiksis dipinjam dari bahasa Yunani untuk pertunjukkan" (Djajasudarma, 2012:50). Khushartini memberikan definisi deiksis sebagai "cara merujuk pada suatu hal yang berkaitan erat dengan konteks penutur, dengan demikian ada rujukan yang bersal dari penutur, dekat dengan penutur, dan jauh dari penutur" (Kushartanti, 2005:111).

Dalam kamus linguistic deiksis memiliki makna "hal atau fungsi yang menunjukkan sesuatu di luar bahasa; kata tunjuk pronominal, ketakrifan, dsb" (Kridalaksana, 2009:45). Pengertian deiksis yang lain dikemukakan oleh Lyons, yang menjelaskan bahwa "deiksis adalah lokasi dan indentifikasi orang, objek, peristiwa, proses atau kegiatan yang sedang dibicarakan atau yang sedang diacu dalam hubungannya dengan dimensi ruang dan waktunya, pada saat dituturkan oleh pembicara atau yang diajak bicara" (Putrayasa, 2014:37). Dengan kata lain informasi kontekstual yang menunjuk pada hal-hal tertentu, baik tempat, ataupun waktu, itulah yang disebut. Hal tersebut membuat penulis tertarik untuk menganalisis tujuan dan konteks penggunaan deiksis dalam acara "Mata Najwa" di televisi. Deiksis luar-tuturan dibedakan menjadi deiksis persona, deiksis ruang, dan deiksis waktu (Purwo, 1984: 7-8. Dalam penelitian ini penulis mengacu pada bagian deiksis menurut Bambang Kaswanti Purwo, yaitu deiksis luar-tuturan yang terdiri dari: deiksis persona, deiksis ruang, dan deiksis waktu.

Acara Mata Najwa merupakan kegiatan berdialog yang menghadirkan pembicara dan narasumber untuk mendiskusikan sebuah topik yang dibahas secara santai dengan dipandu oleh moderator. Kegiatan tersebut di zaman informasi ini, banyak terdapat di siaran televisi, radio, dan youtube. Dalam acara tersebut menghadirkan narasumber untuk membagi informasi dan berbgai macam pengetahuan dan pengelamannya.

Terdapat berbagai acara yang hadir di televisi, radio maupun youtube. Dengan menyajikan gaya yang berbeda-beda, seorang pembicara atau moderator mampu membuat acara tersebut diminati banyak penonton. Acara mata Najwa, mengandung banyak manfaat, diantaranya dapat memberikan informasi berdasarkan pengalaman dan pengetahuan yang didapat pada narasumber.

Acara mata Najwa ini, ditayangkan di Trans-7. Acara ini menghadirkan sosok figur seorang Najwa Shihab, yang dikenal sebagai sosok tokoh yang cerdas 
dan kritis dalam bertanya. Hal ini yang membuat siapa saja yang menontonnya dapat terpukau setiap kali beliau membawakan acara tersebut. Selain itu, dalam program Mata Najwa tersebut mengahdirkan tokoh-tokoh yang banyak menarik perhatian publik. Dengan hadirnya tokoh-tokoh tersebut sebagai narasumber, hal ini membuat acara Mata Najwa dapat memberikan informasi akurat terkait permasalahan yang sedang dibahas.

Tema-tema yang diambil dalam acara Mata Najwa tidak hanya mengangkat permasalahan yang sedang ramai dibicarakan, namun permasalahan lainnya yang jarang diketahui oleh publik. Hal ini membuat acara Mata Najwa sebagai salah satu acara terbaik. Mata Najwa perdana disiarkan di program Metro $T V$ pada tanggal 25 November 2009. Namun acara tersebut resmi berakhir pada tanggal 23 Agustus 2017. Mata Najwa memulai tayangan kedua kembali pada tanggal 10 Januari 2018 di program Trans-7. Program ini ditayangkan setiap hari Rabu pukul 20.00-21.30 WIB.

Terdapat banyak penghargaan yang telah diraih oleh program Mata Najwa, salah satunya pemenang Program Talkshow terbaik dalam program KPAI Awards 2014. Memenangkan berbagai penghargaan, dipandu oleh moderator yang terkenal kritis dan tegas, serta selalu menyajikan tema yang beragam setiap tayangan, membuat penulis tertarik menjadikan acara Mata Najwa sebagai objek penelitian. Sealain itu, acara Mata Najwa sering memberikan situasi semiformal yang menyebabkan pembeicara lebih memperhatikan cara mereka menggunakan bahasa. cara bahasa yang digunakan, juga dapat diamati dari deiksis yang digunakan dalam percakapan, terutama deiksis pesona, ruang, dan waktu.

Penulis menggunakan sistem acak dalam pemilihan tema dan episode untuk dianalisis, sehingga terpilihlah satu tema dan episode untuk dianalisis, yaitu pada bulan April 2020, dengan tema "Jokowi diuji Pandemi". Dengan analisis deiksis pada acara Mata Najwa, diharapkan penelitian ini dapat diaplikasikan dalam pembelajaran Bahasa dan Sastra Indonesia di sekolah khususnya pembelajaran di tingkat "Sekolah Menengah Pertama" (SMP). Siswa dapat lebih mudah memahami maksud sebuah ujaran apabila siswa memahami deiksis pesona, ruang, dan waktu. Begitu juga saat siswa menyajikan data, informasi dalam bentuk teks berita dengan memperhatikan kaidah kebahasaan, yaitu pronominal orang, tempat, dan waktu sesuai dengan konteksnya.

\section{METODE}

Desain penelitian yang digunakan dalam penelitian ini adalah metode deskriptif kualitatif. Penelitian ini adalah meneliti penggunaan deiksis yang terdapat dalam dialog narasumber Mata Najwa di Trans7 (Jokowi diuji Pandemi) episode April 2020. Peneliti mengadakan observasi, pengisian dan pengamatan, penganalisis data, dan penyimpulan. Data yang dikumpulkan bukan bersifat angka, tetapi berbentuk data kualitatif yang dinyatakan dalam bentuk kata-kata. Sebagai suatu kepastian bagi sebuah keadaan hasil penelitian ini akan berisi berbagai kutipan data yaitu kutipan dialog tokoh untuk dideskripsikan dalam kata kajian 
yang komprehensif dan saling terhubung. Deskripsi data yang dianalisis akan ditelaah satu per satu.

Penulis memfokuskan kajian penelitian penggunaan Deiksis pada acara Mata Najwa di Trans7 (Jokowi diuji pandemi) episode April 2020 dan Implikasinya dalam Pembelajaran Bahasa Indonesia dengan langkah-langkah sebagai berikut:

1. Mengumpulkan referensi yang berisi teori kajian pragmatik.

2. Mengamati dan mendengarkan percakapan yang terdapat dalam acara Mata Najwa Jokowi diuji pandemi di Trans7 edisi April 2020.

3. Mentranskripsikan percakapan yang terdapat dalam acara tersebut.

4. Membaca dengan cermat percakapan yang terdapat dalam acara Mata Najwa Jokowi diuji pandemic di Trans7 edisi April 2020 untuk mendapatkan deiksis terdapat di dalamnya.

5. Mengumpulkan data berupa deiksis dan mengelompokkannya menjadi deiksis pesona, deiksis waktu, dan deiksis tempat ke dalam tabel kerja.

6. Mendeskripsikan dan menganaliss data dengan menggunakan sudut pandangan pragmatik.

Sumber data penelitian ini, diperoleh dari percakapan yang terjadi dalam acara Mata Najwa Jokowi diuji pendemi di Trans7 edisi April 2020. Adapun data pada penelitian ini berupa kata dan kalimat yang berbentuk deiksis pesona, deiksis waktu dan deiksis tempat.

Terdapat beberapa macam cara aatau teknik yang digunakan dalam penelitian kualitatif dengan sumber data sekunder. Teknik pengumpulan data yang digunakan penulis pada penelitian ini, yaitu teknik observasi dan teknik dokumentasi. Observasi dilakukan, ketika penulis memperhatikan acara Mata Najwa yang sedang berlangsung di televise kemudian mengadakan pertimbangan. (Arikunto, 2010:272) mengatakan bahwa "mencatat data observasi bukanlah sekedar mencatat, tetapi juga menilai objek tersebut sangat, kurang, atau tidak sesuai dengan yang kita kehendaki”.

\section{HASIL DAN PEMBAHASAN}

\section{Hasil}

Penelitian acara Mata Najwa (Jokowi diuji Pandemi) episode April 2020 merumuskan dua permasalahan, yaitu penggunaan deiksis pada Acara Mata Najwa di Trans 7 (Jokowi diuji Pandemi) episode April 2020 dan Implikasinya terhadap pembelajaran Bahasa Indonesia di SMP. Pada Acara Mata Najwa (Jokowi diuji Pandemi) episode April 2020 ditemukan deiksis persona, ruang, dan waktu.

Mata Najwa adalah salah satu program dialog interaktif di media televisi yang paling banyak mendapat apresiasi oleh masyarakat. Dalam dialog acara Mata Najwa, peneliti banyak menemukan berbagai macam informasi dalam penggunaan deiksis. Berdasarkan data yang sudah dikumpulkan, penggunaan deiksis dengan maksud menyatakan paling banyak ditemukan dalam dialog acara Mata Najwa. 
Levinson dalam Rahardi, (2005:48) mendeskripsikan bahwa pragmatik adalah studi bahasa yang mempelajari relasi bahasa dengan konteksnya. Dalam dialog Mata Najwa, untuk memahami pokok pembahasan yang didiskusikan seorang peserta harus memahami setiap konteks tuturan-tuturan.

Berdasarkan penelitian terhadap Acara Mata Najwa di Trans 7 (Jokowi diuji Pandemi) episode April 2020, terdapat beberapa temuan penggunaan deiksis. Berikut ini merupakan disajikan dalam bentuk tabel temuan penggunaan deiksis yang terdapat pada Acara Mata Najwa di Trans 7 (Jokowi diuji Pandemi) episode April 2020 tersebut.

Tabel 1. Temuan Penggunaan Deiksis pada Acara Mata Najwa di Trans 7 (Jokowi diuji Pandemi) episode April 2020

\begin{tabular}{|c|c|c|c|c|}
\hline \multirow[t]{2}{*}{ No } & \multicolumn{4}{|c|}{ Part 1} \\
\hline & Jenis Deiksis & & xsis & Jumlah \\
\hline \multirow{10}{*}{1} & Deiksis & Pertama & Saya & 20 \\
\hline & Persona & & Kita & 16 \\
\hline & & & Kami & 2 \\
\hline & Deiksis & Lokatif & Ke sana & 1 \\
\hline & Ruang & & Di situ & 1 \\
\hline & & Demonstratif & ini & 14 \\
\hline & & & itu & 11 \\
\hline & $\begin{array}{l}\text { Deiksis } \\
\text { Waktu }\end{array}$ & Lampau & Kemarin & 1 \\
\hline & & & Tadi & 2 \\
\hline & & Mendatang & Nanti & 1 \\
\hline \multirow{11}{*}{2} & \multicolumn{4}{|c|}{ Part 2} \\
\hline & Deiksis & Pertama & Saya & 24 \\
\hline & Persona & & Kita & 11 \\
\hline & & Kedua & Bapak & 2 \\
\hline & & Ketiga & / -nya / & 1 \\
\hline & \multirow{5}{*}{$\begin{array}{l}\text { Deiksis } \\
\text { Ruang }\end{array}$} & & Mereka & 5 \\
\hline & & Lokatif & Ke sana & 1 \\
\hline & & & Di situ & 1 \\
\hline & & Demontratif & ini & 14 \\
\hline & & & itu & 11 \\
\hline & $\begin{array}{l}\text { Deiksis } \\
\text { Waktu }\end{array}$ & Mendatang & Nanti & 4 \\
\hline \multirow{3}{*}{3} & \multicolumn{4}{|c|}{ Part 3} \\
\hline & Deiksis & Pertama & Saya & 11 \\
\hline & Persona & & Kita & 6 \\
\hline
\end{tabular}




\begin{tabular}{|c|c|c|c|c|}
\hline & \multirow{4}{*}{$\begin{array}{l}\text { Deiksis } \\
\text { Ruang }\end{array}$} & \multirow{2}{*}{$\begin{array}{l}\text { Kedua } \\
\text { Ketiga }\end{array}$} & Bapak & 2 \\
\hline & & & Mereka & 5 \\
\hline & & \multirow[t]{2}{*}{ Demontratif } & ini & 8 \\
\hline & & & itu & 5 \\
\hline & $\begin{array}{l}\text { Deisksi } \\
\text { Waktu }\end{array}$ & Kini & Sekarang & 2 \\
\hline \multirow{9}{*}{4} & & \multirow{3}{*}{ Pertama } & & \\
\hline & Deiksis & & Saya & 6 \\
\hline & Persona & & Kita & 9 \\
\hline & \multirow{5}{*}{$\begin{array}{l}\text { Deisksi } \\
\text { Ruang }\end{array}$} & Kedua & Bapak & 2 \\
\hline & & Ketiga & / -nya / & 1 \\
\hline & & Lokatif & Di situ & 1 \\
\hline & & Demontratif & Ini & 6 \\
\hline & & \multirow[b]{2}{*}{ Lampau } & Itu & 5 \\
\hline & $\begin{array}{l}\text { Deiksis } \\
\text { Waktu }\end{array}$ & & Di awal & 1 \\
\hline
\end{tabular}

Berdasarkan temuan penggunaan deiksis prsona pada tabel yang telah diperoleh penggunaan deiksis sangatlah penting dalam berkomunikasi dengan mitra tutur agar mudah dipahami. Hal tersebut bisa dilihat dari percakapan acara Mata Najwa, bahwa semua orang yang berada dalam percakapan acara Mata Najwa menggunakan deiksis terutama deiksis persona. Fungsi deiksis dalam percakapan acara Mata Najwa, berdasarkan data yang telah ditemukan, sebagai kata ganti orang.

Berdasarkan temuan, penggunaan deiksis ruang pada data di atas, penggunaan deisksis sangatlah penting untuk berkomunikasi dengan lawan tutur agar mudah dipahami. Hal ini terbukti, berdasarkan data di atas, diketahui bahwa salah satu cara orang untuk menggambarkan tempat dan objek yang ingin di tuju, yaitu melalui deiksi ruang. Hal ini juga menunjukkan lawan tutur mengetahui dimanakah tempat yang dimaksud oleh penutur. Deiksis ruang berfungsi sebagai penunjuk keterangan tempat.

Berdasarkan temuan deiksis waktu pada acara Mata Najwa di atas, diketahui bahwa cara penutur dan lawan tuturnya memahami tentang waktu, yaitu dengan cara deiksis waktu. Hal ini dikarenakan deiksis waktu berfungsi untuk memudahkan penutur dan lawan tutur dalam mengetahui informasi kapan peristiwa itu terjadi.

Hubungan antara pragmatic dengan pembalajaran juga sangat erat, siswa dapat menerapkan penggunaan bahasa yang baik dan benar. Keterampilan berbahasa siswa bisa ditngkatkan dengan pendekatan pragmatic melalui konteks nyata dan situasi komplek. Terutama dalam mengidentifikasi informasi teks berita. Guru dapat menggunakan tayangan acara Mata Najwa dalam mendapat informasi berupa percakapan liasan, sebagai pedoman dalam mengidentifikasi ciri kebahasaan teks berita dengan bantuan deiksis persona, ruang, dan waktu sebagai 
kata ganti atau pronominal, sehingga dapat membantu siswa dalam mencapai tujuan pembelajaran yang diharpkan.

Berdasarkan penemuan deiksis persona, ruang, dan waktu beserta implikaturnya dalam pembelajaran bahasa Indonesia di atas, dapat disimpulkan bahwa penemuan tersebut mendukung pengertian dari penggunaan deisksis, dan penggunaan deiksis juga dapat dihubungkan dalam pembelajaran Bahasa Indonesia.

\section{Pembahasan}

\section{Deiksis Persona}

Penggunaan deiksis persona pertama tunggal berdasarkan konteks pemakaiannya, antara lain diksi saya dipakai untuk menghormati mitra tuturnya, dipakai dalam situasi semiformal, digunakan untuk berbicara kepada mitra tutur yang tidak saling mengenal, dipakai karena kebiasaan penutur menggunakan ragam formal.

Kushartanti menjelaskan "deiksis persona dapat dilihat pada bentukbentuk pronominal. Bentuk-bentuk pronominal itu dibedakan atas pronominal orang pertama, pronominal orang kedua, dan orang ketiga" (Kushartanti, 2005:111). Sehingga, penulis menyimpulkan bahwa pengertian deiksis pesona ialah kata ganti orang yang berhubungan dengan penutur dan mitra tutur. Deiksis terbagi menjadi 3 jenis, yaitu deiksis persona pertama seperti kata saya, deiksis persona ke dua seperti kata kamu, dan deiksis persona ketiga seperti kata dia.

Penggunaan deiksis persona pertama jamak, antara lain kata kita pada data tersebut digunakan untuk menyatakan dua orang yang sedang berdekatan antara penutur dan mitra tutur, menyatakan keakraban antara penutur dan mitra tuturnya.

Penggunaan deiksis persona pertama jamak, antara lain diksi kami digunakan oleh penutur apabila orang yang dimaksudkan adalah dirinya dan orang yang mewakilinya atau persona pertama sebagai penutur tanpa persona kedua sebagai mitra tutur dan untuk mewakili beberapa orang atau sekelompok orang yang tidak berada dalam situasi tuturan. Penggunaan deiksis persona kedua tunggal, yaitu kata pak digunakan untuk merujuk kepada mitra tutur yang lebih tua dan dihormati.

Penggunaan deiksis persona ketiga tunggal, yaitu kata /-nya/ digunakan untuk penunjuk kepunyaan. Bentuk deiksis persona ketiga jamak, yaitu kata mereka digunakan untuk mengganti orang-orang yang ada dalam suatu tuturan.

\section{Deiksis Ruang}

Deiksis ruang berfungsi sebagai penunjuk keterangan tempat. Jenis deiksis lokatif yang berbentuk frasa di sini, digunakan penutur untuk merujuk pada lokasi tempat penutur berada. Di dalam bahas Indonesia misalnya, kita mengenal di sini, di situ, dan di sana. Cummings berpendapat "referen tempat dalam contoh yang pertama tidak tergantung pada saat pembuatan uajaran. Misalnya dalam kalimat, 'toko terdekat jauhnya dua mil dari sini'. Jarak antar bank dan pabrik obat tetap sejauh sepuluh yard di mana pun penutur ujaran berbeda. Namun, demikian, 
lokasi took bisa dari dua mil jauhnya tergantung pada lokasi penutur (Cummings, 2009: 37).

Preposisi di menggambarkan hal yang diam. Sementara itu, preposisi ked a dari menggambarkan hal yang bergerak. Preposisi di, ke, dan dari dapat diraangkaikan dengan kata penunjuk tempat sini, situ, dan sana, sehingga katakata tersebut disebut sebagai kata penunjuk tempat (pronominal lokatif).

Sistem pronominal demonstratif dalam bahasa Indonesia tidak parallel dengan kata penunjuk tempat; hanya dikenal adanya dua pembedaan pronominal demonstratif ini untuk menunjuk pada benda (tempat) yang dekat dengan persona pertama, dan itu untuk menunjuk pada benda yang jauh dari persona pertama atau yang dekat dengan persona kedua (Purwo, 1984:43).

Jenis deiksis lokatif yang berbentuk frasa di situ, digunakan penutur untuk merujuk pada lokasi yang tidak dekat dengan si penutur dan tidak pula dekat dari mitra tutur. Jenis deiksis lokatif yang berbentuk frasa di sana, digunakan penutur untuk merujuk pada lokasi yang tidak dekat dari penutur dan tidak pula dekat dari lawan tutur. Jenis deiksis lokatif yang berbentuk frasa ini, digunakan penutur untuk merujuk pada objek yang lokasinya dekat dengan si penutur maupun lawan tutur. Jenis deiksis lokatif yang berbentuk frasa itu, digunakan penutur untuk merujuk pada objek yang lokasinya tidak dekat dengan si penutur maupun lawan tutur.

\section{Deiksis Waktu}

Penggunaan penutur dan lawan tuturnya memahami tentang waktu, yaitu dengan cara deiksis waktu. Hal ini dikarenakan deiksis waktu berfungsi untuk memudahkan penutur dan lawan tutur dalam mengetahui informasi kapan suatu peristiwa terjadi.

Deiksis waktu merupakan deiksis yang berhubungan dengan waktu yang terjadi dalam suatu pembicaraan antara penutur dan mitra tutur. "Kata sekarang bertitik labuh pada saat si pembicara mnegucapkan kata itu (dalam kalimat), atau yang disebut tuturan. Kata kemarin bertitik labuh pada satu hari sebelum tuturan dan kata besok bertitik labuh pada satu hari sesudah tuturan". Selain itu terdapat pula bentuk kata deiksis lainnya, seperti dulu, nanti, tadi, kelak. "Kata dulu dan tadi beritik labuh pada waktu sebelum saat tuturan; dulu menunjuk lebih jauh ke belakang daripada tadi. Kata nanti dan kelak bertitik labuh pada waktu sesudah saat tuturan; kedua kata ini dapatt sama-sama menunjuk jauh ke depan”.

Jenis deiksis waktu, yaitu deiksis waktu (lampau), deiksis waktu (mendatang). deiksis waktu (kini). Pemakaian deiksis waktu (lampau), antara lain bentuk kata kemarin, merujuk pada waktu sebelum tuturan dituturkan oleh penutur kepada lawan tutur. Bentuk kata tadi merujuk pada waktu sebelum tuturan dituturkan oleh penutur kepada lawan tutur. Bentuk nanti merupakan deiksis waktu yang akan datang karena merujuk pada waktu setelah tuturan diucapkan namun waktunya tidak pasti/luas. Kata sekarang merupakan deiksis waktu sekarang karena merujuk pada waktu saat terjadinya tuturan. 


\section{Implikasi dalam Pembelajaran Bahasa Indonesia}

Implikasi penelitian terhadap pembelajaran Bahasa dan Sastra Indonesia sangat berhubungan dan relevan. Sebagaimana kurikulum 2013 revisi 2017 kelas VIII SMP yang telah diterapkan, terdapat Kompetensi Dasar yang harus dicapai oleh siswa dalam materi teks berita, salah satunya yakni menyajikan data, informasi dalam bentuk teks berita dengan memperhatikan kaidah kebahasaan, yaitu kata ganti orang pertama, kedua, dan ketiga, kalimat langsung dan tidak langsung, penggunaan konjungsi yang sesuai dengan konteks penggunaannya. Penelitian ini dapat membantu siswa untuk dapat lebih mudah memahami maksud sebuah ujaran apabila siswa memahami deiksis persona, ruang, dan waktu.

\section{SIMPULAN}

Berdasarkan hasil penelitian terhadap Acara Mata Najwa di Trans 7 (Jokowi diuji Pandemi) episode April 2020 dan Implikasinya terhadap pembelajaran Bahasa Indonesia di SMP adalah terdapat penggunaan deiksis persona pada data yang telah diperoleh penggunaan deiksis sangatlah penting dalam berkomunikasi dengan mitra tutur agar mudah dipahami. Hal tersebut bisa dilihat dari percakapan acara Mata Najwa, bahwa semua orang yang berada dalam percakapan acara Mata Najwa menggunakan deiksis terutama deiksis persona. Fungsi deiksis dalam percakapan acara Mata Najwa, berdasarkan data yang telah ditemukan, sebagai kata ganti orang. Penggunaan deiksis ruang pada data di atas, penggunaan deisksis sangatlah penting untuk berkomunikasi dengan lawan tutur agar mudah dipahami. Hal ini terbukti, berdasarkan data di atas, diketahui bahwa salah satu cara orang untuk menggambarkan tempat dan objek yang ingin di tuju, yaitu melalui deiksi ruang. Hal ini juga menunjukkan lawan tutur mengetahui dimanakah tempat yang dimaksud oleh penutur. Deiksis ruang berfungsi sebagai penunjuk keterangan tempat. Deiksis waktu pada acara Mata Najwa di atas, diketahui bahwa cara penutur dan lawan tuturnya memahami tentang waktu, yaitu dengan cara deiksis waktu. Hal ini dikarenakan deiksis waktu berfungsi untuk memudahkan penutur dan lawan tutur dalam mengetahui informasi kapan peristiwa itu terjadi. Implikasi penelitian terhadap pembelajaran Bahasa dan Sastra Indonesia sangat berhubungan dan relevan. Sebagaimana kurikulum 2013 revisi 2017 kelas VIII SMP yang telah diterapkan, terdapat Kompetensi Dasar yang harus dicapai oleh siswa dalam materi teks berita, salah satunya yakni menyajikan data, informasi dalam bentuk teks berita dengan memperhatikan kaidah kebahasaan, yaitu kata ganti orang pertama, kedua, dan ketiga, kalimat langsung dan tidak langsung, penggunaan konjungsi yang sesuai dengan konteks penggunaannya. Penelitian ini dapat membantu siswa untuk dapat lebih mudah memahami maksud sebuah ujaran apabila siswa memahami deiksis persona, ruang, dan waktu.

Merujuk simpulan yang telah diberikan, maka saran-saran yang dapat yang diberikan adalah penelitian ini diharapkan dapat mendorong penelitian lain, agar meneliti percakapan yang terjadi pada acara di Mata Najwa Trans 7 ataupun acara lainnya dengan fokus pada jenis deiksis yang lain secara lebih mendalam lagi 
ataupun membahas percakapan pada acara dari persoalan yang berbeda selain penggunaan deiksis. Penelitian ini diharapkan dapat menjadi bahan pembelajaran bagi guru untuk dapat memaksimalkan pengajaran bahasa dan sastra Indonesia. Teori deiksis persona, ruang, dan waktu dapat disampaikan kepada siswa saat menyampaikan materi pembelajaran yang berhubungan dengan keterampilan menyimak/berbicara/menulis dan menerapkan bentuk penggunaan deiksis dalam menganalisis informasi teks diskusi.

\section{DAFTAR PUSTAKA}

Arikunto, S. (2010). Prosedur penelitian: Suatu pendekatan praktik (Edisi Revisi Cetakan 14). Jakarta: PT Rineka Cipta.

Cummings, L. (2007). Pragmatik. Yogyakarta: Pustaka Pelajar

Djajasudarma, F. (2012). Wacana dan pragmatik. Bandung: PT Refika Aditama.

Kridalaksana, H. (2009). Kamus linguistik (Edisi Keempat-Cetakan Kedua). Jakarta: PT Gramedia.

Kushartanti, U. Y., \& Lauder, M. R. (2005). Pesona bahasa: Langkah awal memahami linguistik. Jakarta: Gramedia Pustaka Utama.

Nurgiyantoro, B. (2018). Teori pengkajian fiksi. Yogyakarta: UGM Press.

Purwo, B. K. (1984). Deiksis dalam bahasa Indonesia. PT Balai Pustaka (Persero).

Putrayasa, I. B. (2014). Pragmatik. Yogyakarta: Graha Ilmu.

Rahardi, R. K. (2005). Pragmatik: Kesantunan imperatif bahasa Indonesia. Erlangga.

Tarigan, H. G. (2009). Pengajaran pragmatik. Bandung: Angkasa.

Yule, G. (2006). Pragmatik.Yogyakarta: Pustaka Pelajar. 